\title{
Demografik Değişkenlerin Lider-Üye Etkileşimi Üzerindeki Etkisinin Lojistik Regresyon Analizi ile Belirlenmesi: Konaklama İşletmelerinde Bir Araştırma
}

\author{
Determination of the Effect of Demographic Variables on Leader-Member Exchange \\ by Logistic Regression Analysis: A Research in Accommodation Establishments
}

\author{
Eray POLAT*
}

$\ddot{O} Z$

Turizm sektörünün emek-yoğun yapısı, çalışanların gerek kendi aralarında gerek liderleri ile üst düzey bir iletişim kurmalarını gerekli ve önemli kılmaktadır. Bu araştırmada, çalışanların liderleri ile olan iletişimleri üzerinde durulmuş ve iki temel soruya cevap aranmıştır. Bu sorulardan ilki, konaklama işletmelerindeki alt düzey çalışanların lider-üye etkileşimi (LÜE) algısının hangi düzeyde olduğu konusu ile ilgiliyken, ikincisi bazı demografik değişkenlerin LÜE algisı üzerinde hangi yönde ve ne derece etkisi olduğu ile ilgilidir. Nicel araştırma yöntemlerinin kullanıldı̆̆ araştırmada, Balıkesir ilinde bulunan konaklama işletmelerinde alt düzey çalışanlar ile yüz yüze görüşülmüş ve anket tekniği ile veri toplanmıştır. Illk araştırma sorusuna cevap bulabilmek amacılla ölçek ortalaması hesaplanmış; diğer sorunun cevabını bulabilmek ise ikili lojistik regresyon analizi ile mümkün olmuştur. Sonuçlara göre konaklama işletmelerindeki alt düzey çalışanların LÜE alglsı yüksek düzeydedir. Ayrıca yaş, aylık gelir, eğitim durumu, çalışma biçimi, işletme deneyimi ve sektör deneyimi değişkenlerinin LÜE algısı üzerinde anlamlı etkilerinin olduğu da görülmüştür. Ek olarak bu değişkenlerin etkilerinin LÜE'nin alt boyutlarına göre hem yön olarak hem de etkinin derecesi olarak farklılaştı̆̆ da belirtilmelidir. Ancak tüm alt boyutları etkilemesi bakımından sektör deneyiminin en önemli değişken olduğu ifade edilebilir. Zira sektör deneyimi ile birlikte L ÜE algısı önemli oranda artmaktadır.

\section{ANAHTAR KELIMELER}

Lider-Üye Etkileşimi, Alt Düzey Çalışanlar, Konaklama İşlemeleri, Lojistik Regresyon Analizi.

\begin{abstract}
The labor-intensive structure of the tourism sector makes it necessary and important for employees to establish a high level of communication between themselves and with their leaders. In this research, the communication of the employees with their leaders was emphasized and answers to two basic questions were sought. The first of these questions relates to the level of perception of leader-member exchange (LMX) of the lower-level employees in the accommodation establishments, while the second is about the direction and extent of some demographic variables on LMX perception. In the study, where quantitative research methods were used, face-to-face interviews were conducted with low-level employees in accommodation establishments in Ballkesir province and data were collected by questionnaire technique. In order to find an answer to the first research question, the scale mean was calculated; the answer of the other question was ascertained by binary logistic regression analysis. According to the results, the employees of the lower-level in the accommodation establishments have a high level of LMX perception. Besides, age, monthly income, educational status, working style, operational experience and industry experience were found to have significant effects on LMX perception. In addition, it should be noted that the effects of these variables are differentiated both in terms of direction and degree of effect according to the sub-dimensions of the LMX. However, it can be said that the industry experience is the most important variable in terms of affecting all the sub-dimensions. Because, with the increase of the sector experience, the perception of the LMX increases significantly as well.
\end{abstract}

\section{KEYWORDS}

Leader-Member Exchange, Lower Level Employees, Accommodation Establishment, Logistic Regression Analysis.

\begin{tabular}{|c|c|c|}
\hline \multicolumn{2}{|r|}{$\begin{array}{c}\text { Makale Geliş Tarihi / Submission Date } \\
\text { 21.03.2019 }\end{array}$} & $\begin{array}{c}\text { Makale Kabul Tarihi / Date of Acceptance } \\
\text { 05.11.2019 }\end{array}$ \\
\hline Atıf & $\begin{array}{l}\text { Polat, E. (2019). Demografik Değişken } \\
\text { Belirlenmesi: Konaklama İşletmelerin } \\
\text { Dergisi, } 22 \text { (2), 742-757. }\end{array}$ & $\begin{array}{l}\text { Imi Üzerindeki Etkisinin Lojistik Regresyon Analizi ile } \\
\text { cuk Üniversitesi Sosyal Bilimler Meslek Yüksekokulu }\end{array}$ \\
\hline
\end{tabular}

\footnotetext{
* Arş. Gör. Dr., Gümüşhane Üniversitesi Turizm Fakültesi, eraypolat38@gmail.com, ORCID: 0000-0003-1470-4298
} 


\section{GİRIŞ}

Günümüz işletmeleri arasında sürdürülebilir rekabet avantajı elde etmede en önemli gerekliliklerden birisi, işletme çalışanlarının bu sürece aktif bir şekilde dahil edilmesi ve bu amaca yönelik motive edilmesidir. Bunun için, çalışanların bu sürece ya direktiflerle zorlanarak ya da gönüllü ve işbirlikçi bir şekilde dahil edilmesi şeklinde iki seçenek bulunmaktadır (Eşitti ve Kasap, 2019). Bu noktada çalışanların hem kendi aralarında hem de yöneticileri olan iletişim biçimi, bu iletişimin düzeyi ve etkinliği büyük önem kazanmaktadır. Bu açından, konaklama işletmelerini diğer işletmelerden ayrı bir kefede değerlendirmek hatalı olacaktır. Çünkü bu işletmeler söz konusu olduğunda da işletme hedeflerini benimsemiş, motive olmuş ve problem çözme becerisi yüksek, özgüveni ve öz-yeterlilik düzeyi yüksek çalışanların önemi yadsınamaz. İşletmelerin bu yeterliliklere sahip çalışanlar ve yöneticilerle hedeflerini istenilen şekilde gerçekleştirebileceği dile getirilse de bu, tek başına yeterli olmayabilir. Çünkü konaklama işletmelerindeki emek-yoğun işleyiş̧, diğer bir ifadeyle iş süreçlerinin otomasyondan ziyade insan odaklı ilerlemesi, çalışanlar arasındaki iletişimi ve bunun etkinliğini önemli bir noktaya taşımaktadır. Bu bağlamda LÜE kuramı, çalışan-yönetici arasındaki etkileşimi açılamayı amaç edinmiş önemli bir teori olarak görülebilir.

LÜE'nin temel savlarından biri, liderin bütün astlarına eşit derecede yakınlık gösteremediği ve kimileri ile daha yakın, kimileri ile daha mesafeli ilişkiler kurduğu yönündedir. Kurama göre, yakın ilişkiler kurulan bireyler iç grup, mesafeli ilişkiler görülen bireyler ise $d \iota s ̧$ grup olarak adlandırılmaktadır. Bu gruplarda yer almayı etkileyen faktörlerden biri, bireylerin demografik özellikleridir. İşte bu araştırmada, alt düzey çalışanlar açısından demografik özelliklerin, LÜE algısı üzerinde ne kadar etkili olduğu ikili lojistik regresyon analizi yardımıyla tespit edilmeye çalışılacaktır.

Yazında konaklama sektöründe çalışanların LÜE algılarını tespite yönelik araştırmaların sınırlı düzeyde olduğu görülmektedir. Bu nedenle bu araştırma ile yazındaki boşluğa katkı sağlanacağı düşünülmektedir. Ayrıca sınırlı düzeyde de olsa, çalışanların demografik özelliklerinin iç ya da dış grupta yer almaya olan etkisini anlamamıza yardımcı olarak bulgular sunulmaktadır. Ancak herhangi bir demografik karakterin bunu ne derece etkilediği konusunda bir araştırmaya rastlanılmamıştır. Bu noktada araştırmanın cevap bulmayı amaçladiğ 1 temel problemler şu şekilde ifade edilmelidir:

- Konaklama işletmelerinde alt düzey çalışanların LÜE algısı hangi düzeydedir?

- Demografik değişkenler, LÜE algısını hangi yönde ve ne derece etkilemektedir?

\section{KAVRAMSAL ÇERÇEVE VE ÍLGILİ ALANYAZIN}

Örgütlerde yönetici ve işgörenler arasındaki ilişkileri açıklamayı amaç edinmiş birbirinden farklı liderlik teorileri bulunmaktadır. Özellik teorileri, davranışsal teori ya da güç teorisi gibi farklı isimlerle anılan geleneksel liderlik teorilerinde (Kim vd., 2010: 591) daha çok liderin, üyeleri ile ilgili farklı durumlarla karşılaştığında ne tür davranışlar sergileyebileceği ya da sergilemesi gerektiği gibi konular üzerinde durulmaktadır (Cevrioğlu, 2007: 20). Aynı zamanda bu kapsamda değerlendirilen teorilerde iki temel varsayım bulunmaktadır. Bunlardan ilki, liderin tüm üyelere homojen bir şekilde davrandığı varsayımı iken (Liden ve Graen, 1980: 451; Kim vd., 2010: 531); ikincisi, üyelerin algılama, yorumlama ve bunun sonucunda davranış geliştirme gibi faktörler açısından aynı özellikler taşıdığıdır (Baş vd., 2010: 1015; Katı, 2016: 21). Buna göre bu yaklaşımların genel çerçevesinde tek tip ast-üst ilişkisinin gerçekleştiği de söylenebilmektedir (Çekmecelioğlu ve Ülker, 2014: 36).

LÜE kuramı, temel olarak bu noktada geleneksel liderlik kuramlarından ayrılmaktadır. İlk kez Dansereau ve arkadaşları tarafından 1970'li yıllarda “Dikey-İkili Bağlantı Kuramı” olarak dile getirilen kuramda, liderin her bir üyeye aynı liderlik tarzı ile yaklaşamayacağı ve böylelikle kurulan ilişkinin diğerlerine göre farklı olabileceği ileri sürülmektedir (Wang, 2016: 971; Cha ve Borchgrevink, 2018: 236).

Kuram, temelinde farklı teorileri barındırmaktadır. Bunlardan birisi rol teorisidir. Bu teoriye göre lider ile üyeler arasındaki dikey ikili ilişkiler rol geliştirme sürecine dayanır. Rollerin gelişim sürecinde ise yazılı iş tanımları veya diğer resmi belgeler ile birlikte "rol geliştirme süreci" denilen resmi olmayan bir süreç de etkin olmaktadır (Liden vd., 1997: 49; Cevrioğlu, 2007: 24). Özellikle işgörenlerin yeni işe başladıkları dönemde, lider ile üye arasındaki çeşitli ilişkilerin düzeyi ve seyri, rol geliştirme sürecinde belli olmaya başlamakta ve lider ile üye arasındaki etkileşimin niteliği belirmektedir (Çekmecelioğlu ve Ülker, 2014: 38). Kuramın gelişimine katkı sağlayan bir diğer teori ise sosyal mübadele teorisidir. Buna göre lider ile üye arasındaki etkileşim, sosyal mübadeleye dayanmaktadır (Baş vd., 2010: 1017). Zira bu etkileşim sırasında bilgi, tavsiye, arkadaşlık ya da iş çıktıları gibi maddi veya manevi faktörler değişme konu olmaktadır (Liden ve Maslyn, 1998: 45). Bu süreç boyunca taraflar arasındaki etkileşimin seviyesi, beklentilerin karşılanmasına göre şekillenmekte ve üyelerin liderle ilişkisinin standart bir hal almasını engellemektedir. 


\section{Şekil 1. Geleneksel Liderlik Kuramları ve Lider-Üye Etkileşimi Kuramlarında Lider-Üye İlişkisi}

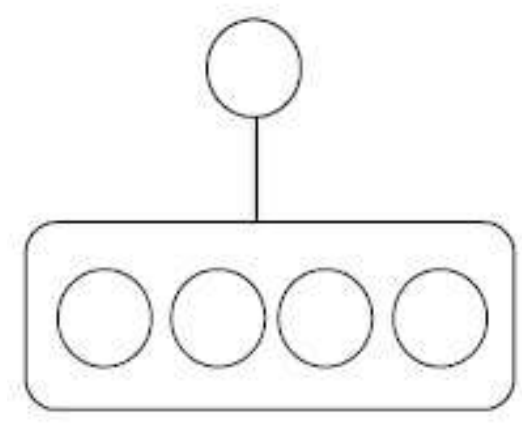

Geleneksel Liderlik Kuramları

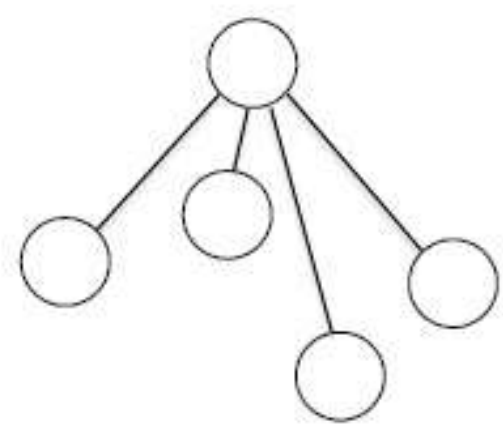

Lider-Üye Etkileşimi

Kaynak: Dansereau vd. (1973:187-188).

Gerek rol teorisi gerekse de sosyal mübadele teorisinden beslenen LÜE kuramında liderin zaman, dikkat ve kaynak gibi kısıtlara sahip olması nedeniyle her bir üye ile her an yüksek kalitede bir ilişki kuramayacağı da pekâlâ belirtilebilir. Bunun yerine kuramda, lider ile üye arasındaki ilişkinin yüksek kaliteden düşük kaliteye uzanan bir yelpazede olabileceği öne sürülmektedir (Lai vd., 2018: 1973; Martin vd., 2018: 151). Ancak temelde iki tür davranış biçimi ortaya çıkmaktadır (Alparslan ve Oktar, 2015: 109). Buna göre daha yakın ilişkiler geliştirilen grup iç grup; daha mesafeli durulan üyeler ise dış grubu oluşturmaktadır (Kim ve George, 2005: 470).

İç grup, yüksek kaliteli grup olarak da adlandırılır. Bu grupta yer alanlar, karar alma süreçlerine katılmakta, ek sorumluluk ve yetkilere sahip olarak kaynaklara daha kolay ulaşabilmektedirler (Alparslan ve Oktar, 2015: 109; Estiri vd., 2018: 271). Aynı zamanda liderler onları resmi ve gayri resmi olarak daha çok ödüllendirmeye meyillidir. Düşük kaliteli grup olarak da adlandırılan dış gruptaki işgörenlerle ise daha farklı bir iliş̧ki görülmektedir. $\mathrm{Bu}$ etkileşimde, görece daha düşük düzeyli bir etkileşim görülmesi ile birlikte liderin bu gruptakilere karşı genellikle pozisyon güçlerini kullanarak resmi kural-politika, otorite ilişkileri ya da iş sözleşmelerine dayalı olarak ilişki kurması söz konusudur (Bolat vd., 2017: 88). Lider, düşük kaliteli ilişki kurduğu bu gruptakilerden, görev ve sorumluluklarını yerine getirmelerini yine bekler. Üyeler ise kendilerinden beklenen bu görev ve sorumlulukları yerine getirdikleri ölçüde, yine resmi olarak tanımlanmış haklarını alırlar. Sonuç olarak lider, üyelerden beklediği performansı yine yeterli düzeyde elde etmiş olur (Bolat, 2011a: 257).

İç gruptaki üyeler, lider ile daha sıkı bir iletişim kurabilmekte ve daha çok destek görebilmektedir. Ancak bunun, grup performansları arasındaki farkın gittikçe artabilmesi şeklinde olumsuz bir yanı ortaya çıkabilir. Çünkü lider iç gruptaki üyelere daha önemli ve daha çok takdir görebilecek işleri vermekte; diğer gruba ise önem derecesi görece daha düşük, tekrar eden ve daha az istenilen işleri vermektedir. Bu da iki grubun performansının giderek farklılaşmasına sebep olmaktadır (Martin vd., 2010: 45; Alparslan ve Oktar, 2015: 110). Bu nedenledir ki, bu iki grubun keskin sınırlarla ayrımı istenmeyen bir durumdur. Aksi halde diş grupta yer alan üyeler kendilerine gösterilen davranışlar ve statülerine karşılık, olumsuz davranışlar geliştirebilirler (George ve Jones, 2012: 354). Aynı zamanda denilebilir ki, lider iç grubunu, dış grubu ile artıracaktır. İstenen de büyük bir iç gruba karşılık küçük bir dış gruba sahip olmaktır (Alparslan ve Oktar, 2015: 110).

Öte yandan LÜE ortaya atıldığ 1 ilk yıllarda tek boyutlu bir kavram olarak ele alınmıştır. Bu konuda hazırlanmış ilk ölçeklerden birini ortaya koyan Liden ve Graen (1980)'de, lider ile üye arasındaki etkileşimin boyutlarına odaklanmadan sadece etkileşimin düzeyine odaklanarak tek boyuta katkı sağlamıştır. Tek boyutlu ölçeklere, Graen, Novak ve Sommerkamp tarafından 1982 yılında ortaya konulan ve 1990'lı yıllarda sıklıkla kullanılan LMX-7 ölçeği diğer bir örnek olarak verilebilir (Gerstner ve Day, 1997: 828). Ancak sonraki yıllarda, LÜE kuramının temelini oluşturan gerek rol teorisi gerek sosyal mübadele teorisinin çok boyutlu yapılardan oluşması, bu kuramın da çok boyutlu bir model ile daha iyi açıklanabileceği fikrini gündeme getirmiştir (Liden ve Maslyn, 1998: 45). Bu gelişmelere bağl1 olarak Dienesch ve Liden (1986: 624-625) yaptıkları çalışmada, lider ile üye arasındaki ilişkinin "etki, bağlılık ve katkı" olmak üzere üç alt boyutlu bir yapıda olabileceğini iddia etmişlerdir. Liden ve Maslyn (1998) ise bu boyutlara "profesyonel saygı" boyutunu da eklemiş ve dört alt boyutlu bir ölçek geliştirmişlerdir. Özellikle 2000 yılı sonrasında konu hakkında yapılan çalışmalarda Liden ve Maslyn (1998) tarafindan ortaya konulan ölçeğin, daha çok kabul gördüğü ve daha 
sıklıkla kullanıldığı görülmektedir (Baş vd., 2000: 1018). Bu boyutları aşağıdaki gibi açıklamak olanak dahilindedir.

Katkı, iş odaklı faaliyetlerde ikilinin açık veya örtülü ortak amaçlarını gerçekleştirmeye yönelik yeterli miktarda, istenilen yönde ve kaliteli hizmet vermesi ile ilgilidir (Dienesch ve Liden, 1986: 624). Özellikle ikili arasındaki etkileşimin başlangıcında lider, üyelerin performansını verilen görevlere odaklanarak değerlendirecektir. Görevlerini istenilen şekilde yerine getiren üyeler, bunu yapamayanlara göre liderle daha kaliteli bir etkileşim kuracaklardır. Etkileşimin kalitesi ile birlikte liderin üyeye sağladığı imkânların sınırı ve kalitesi de artacaktır (Liden ve Maslyn, 1998: 45). Böylelikle etkileşimin kalitesi daha da artacak ve bu üyeler iç gruba dahil olabilecektir. Verilen görevleri daha düşük performansla yapan üyeler ise dış grupta kalarak bu imkanlardan faydalanamayacaktır.

Bağlılık, ikilinin birbirine ne derece sadık olduğuyla ilgilidir. Bir başka ifadeyle bağlılık, lider ile üyenin karşılıklı olarak davranışlarını üçüncü kişilere ya da topluma karşı ne derece desteklediği ile ilgilidir. Bağl1lık, LÜE'nin sağlanması ve devam ettirilmesinde kritik role sahip olan bir boyuttur (Liden ve Maslyn, 1998: 46). Denilebilir ki, liderler sorumluluk isteyen ve bağımsız karar alınması gereken görevleri kendilerine daha sadık hissettikleri üyelerine vermeyi tercih ederler (Kat1, 2016: 28).

Etki, taraflar arasındaki iş ya da profesyonel değerlerden çok kişiler arası yakınlığa dayanan ya da arkadaşlık temelinde gelişen ilişkiyi ifade etmektedir. Taraflar arasında sadece işe dayalı bir ilişki olduğunda, etki boyutu ya çok az öneme sahip olacak ya da hiçbir anlam ifade etmeyecektir (Baş vd., 2010: 1019). Böyle bir durumda anlam kazanacak boyut, katkı boyutudur (Katı, 2016: 29). Ancak bazen kişiler arası arkadaşlığın ya da yakınlığın ön plana çıktığı durumlarda, etki boyutu etkileşimin kalitesini tek başına belirleyecek kadar güçlü de olabilir (Baş vd., 2010: 1019).

Mesleki Saygı, "tarafların organizasyon içinde ya da dışında sahip olduğu saygınlık derecesine yönelik algı" olarak tanımlanmaktadır. Bu algı, o kişinin geçmiş tecrübelerinden, organizasyon içinde ya da dışında o kişi hakkında konuşulanlardan, kişinin aldığı ödül ya da diğer tanınma araçlarından kaynaklanabilir. Ayrıca bu mesleki saygının, o kişiyle çalışmaya başlamadan önce oluşabileceği de söylenebilir (Liden ve Maslyn, 1998: 50).

Ortaya atıldığı süreden beri geçen 40 y1lda LÜE kuramı hakkında yapılan çalışmalar, işgörenlerin iş tutumları, iş çıktıları ya da bireysel-grup performansı gibi konular ile ilgili olarak yapılan çalışmalara önemli katkılar yapmıştır (Cha ve Borchgrevink, 2018: 235). Aynı zamanda bu çalışmalarda kuramı destekleyen sonuçlar da elde edilmiştir. Örneğin, Murphy ve Ensher (1999), öz-yeterlik düzeyi yüksek olan çalışanların, düşük olanlara nispeten daha yüksek iş performansına sahip olduklarını, lider tarafından daha çok desteklendiklerini ve bu sayede ikili arasındaki etkileşimin daha yüksek düzeyde gerçekleştiğini tespit etmiştir. Buna paralel olarak farklı sektörlerde yapılan çalışmalarda LÜE'nin örgütsel adalet algısını olumlu yönde etkilediği (Erdogan vd., 2006), bireysel ve örgütsel performansı artırdı̆̆ı (Liden vd., 2006), örgütsel vatandaşlık davranışlarının gelişmesine ve artmasına yol açtığı (Ilies vd., 2007), örgütsel bağlılı̆̆ 1 artırdığı (Joo, 2010) gibi sonuçlar elde edilmiştir. Dahası, meta-analiz çalışmaları yapan Gerstner ve Day (1997), LÜE’nin işgören devir hızını, Martin vd. (2016) ise üretim karşıtı iş davranışlarını azalttığını tespit etmiştir.

Mesele, turizm sektörü açısından ele alındığında ise lider ile üye arasındaki etkileşim konusunun önemi daha belirgin hale gelmektedir. Ancak genel manada turizm sektöründe LÜE kuramı özelinde yapılmış çalışmaların yönetim-organizasyon yazını içinde oldukça küçük bir alan kapladığı da dile getirilebilir (Cha ve Borchgrevink, 2018: 234). Bunun, şaşırtıcı bir durum olduğu söylenebilir. Çünkü turizm sektöründe işlerin büyük oranda ve güçlü bir şekilde insani ilişkilere dayalı yürümesi, lider ile üyenin etkileşim düzeyinin yüksek olmasını önemli hale getirmektedir. Nitekim turizm sektöründe, konu hakkında yapılmış çalışmalarda, diğer sektörlerde yapılan çalışmalara benzer olarak LÜE düzeyinin yüksek olması ile birlikte iş ya da örgüt çıktılarının da istenilen düzeylerde olduğu ortaya konmuştur. Örneğin Garg ve Dhar (2016) Hindistan'da yürüttükleri çalışmada lider ile yüksek düzeyli bir etkileşim içerisinde olan çalışanların, işyerinde ekstra roller almaya daha gönüllü olduklarını ifade ederken, Kim ve George (2005) bu çalışanların işyerinde daha etkin olduklarını belirtmektedir. Buna uygun olarak Wang (2016) da LÜE'nin artması ile performansın da artacağını rapor etmektedir.

Yine turizm sektörü özelinde yapılmış çalışmalardan Liao vd. (2009), LÜE-örgütsel bağl1lık arasında, Chow vd. (2015) ile Estiri vd. (2018) LÜE-örgütsel vatandaşlık davranışları arasında pozitif ilişkiler tespit etmiştir. Lai vd. (2018) yüksek düzeyli LÜE’nin duygusal tükenmişliği, Kim vd. (2010) işten ayrılma niyetini azalttığını dile getirmektedirler. Türkiye'de yapılan sınırlı sayıda çalışmada ise farklı ülkelerde yapılan çalışmalardakine benzer sonuçlar elde edildiği görülmektedir. Örneğin Bolat (2011b) ile Kaşlı ve Seymen 
(2010) LÜE’nin tükenmişlik, Demirci (2017) işten ayrılma niyeti, Tanrıverdi ve Kahraman (2016) işe yabancılaşma ile ilişkisine bakmış ve aralarında negatif korelasyonlar tespit etmişledir.

Demografik özelliklerin de lider ile üye arasındaki ilişkinin gücüne etki edebileceğini ifade eden çalışmalar bulunmaktadır. Daha açık bir ifadeyle, yaş, cinsiyet, ırk, kıdem ve eğitim gibi demografik değişkenler bakımından benzerlikler taşıyan lider ile üye arasında, sosyal kimlik teorisine de uygun olarak (Pichler vd., 2019: 22), etkileşimin daha kolay kurulacağı ve sürdürülebileceği dile getirilmektedir (Green vd., 1996: 204; Epitropaki ve Martin, 1999; 238; Brouer vd., 2009: 61). Endüstriyel ve örgütsel psikoloji yazınında geçerli olan, demografik benzerliklere sahip bireylerin birbirlerine karşı daha fazla psikolojik yakınlık hissedecekleri ve böylelikle kişisel etkileşimlerinin de yüksek düzeyde gerçekleşebileceği düşüncesi buna dayanak olarak gösterilebilir (Tsui ve O'Reilly, 1989: 404; Tsui vd., 1992: 550). Demografik benzerliklerin özellikle etki boyutunu etkileyeceği ve taraflar arasındaki etkileşimi de artıracağı öne sürülmektedir (Liden vd., 1993: 664). Bu konu çalışmaların bazılarında geçerlilik kazanmasa da (Liden vd., 1993), Green vd. (1996: 204) tarafindan genel olarak kabul gördüğü de dile getirilmektedir.

Bazı araştırmacılar ise gerçekte mevcut olan demografik benzerlikten ziyade algılanan benzerliğin LÜE üzerinde daha etkili olduğunu ileri sürmektedir. Bu ise sosyal biliş teorisinde geçerli olan, bireylerin benzerliklerinin gerçekte mevcut olmasındansa, buna yönelik hangi duyguyu taşıdıklarının daha önemli olduğu fikrine dayandırılmaktadır (Martin vd., 2010: 48). Nitekim kimi çalışmalarda bu husus geçerlik kazanmışır (Dulebohn, 2012: 1723). Özetle, hem gerçekte var olan hem de algilanan demografik benzerlik ile LÜE’nin ilişkili olduğu söylenebilir.

\section{YÖNTEM}

Araştırmanın amacı, konaklama işletmelerinde görev yapan alt düzey çalışanların, yöneticileri ile aralarındaki etkileşimi hangi düzeyde algıladıklarını tespit etmektir. Emek-yoğun bir sektör olan konaklama sektöründe bireyler arasındaki iletişim ve etkileşim kalitesinin, hizmet kalitesi ve müşteri memnuniyeti gibi konularla doğrudan ilişkili olması, çalışanların hem kendi aralarındaki hem de yöneticileri ile olan iletişim ve etkileşim düzeyini önemli hale getirmektedir. Bu nedenle, bunu ortaya koymayı amaç edinmiş çalışmanın önem taşıdığı düşünülmektedir. Ayrıca bu konu hakkında konaklama sektörü çalışanları özelinde yapılmış çalışma sayısının oldukça sınırlı olması da bu araştırmayı önemli kılan bir diğer husus olarak değerlendirilebilir.

Araştırmanın bir diğer amacı ise bazı demografik değişkenlerin LÜE’ye olan etkisini ortaya koyabilmektir. Yazında, demografik değişkenler bakımından hangi grubun yüksek/düşük LÜE algısına sahip olduğunu inceleyen çalışmalar görülmektedir. Daha açık bir ifadeyle örneğin cinsiyet bakımından erkek ya da kadınlardan hangisinin yüksek/düşük LÜE algısına sahip olduğu konusunun ele alındığı görülmektedir. Ancak bu demografik değişkenlerden hangisinin LÜE algısını ne derece ve hangi yönde etkilediğini inceleyen çalışmanın -araştırmacının bilgisi dahilinde- mevcut olmadığı görülmektedir. Bu nedenle, bu çalışma ile yazına bu anlamda katkı sağlayabileceği düşünülmektedir.

Kuramsal ve saha araştırması olarak iki aşama halinde gerçekleştirilen bu araştırmada birincil verilerin toplanması maksadıyla anket formu kullanılmıştır. $\mathrm{Bu}$ anket formu, otel çalışanları ile yüz yüze görüşülmek suretiyle uygulanmıştır. Anket formunun daha önce yerli yazındaki çalışmalarda sıklıkla kullanılması ve bu çalışmada da benzer şekilde kullanılması nedeniyle anlaşılabilirliği konusunda bir problemin olmayacağı düşünülmüş ve pilot uygulama yapılmamıştır.

Anket formu iki bölümden oluşmaktadır. İlk bölümü kişisel bilgi formu oluştururken, ikinci bölümde Liden ve Maslyn (1998) tarafindan geliştirilen ve her biri üç ifade içeren sevgi, sadakat, katk1 ve mesleki sayg1 boyutlarından oluşan LÜE ölçeğine yer verilmiştir. Ölçek Baş vd. (2010) tarafindan Türkçe'ye çevrilmiş ve yüksek derecede geçerlik ve güvenirliğe sahip olduğu belirlenmiştir. Ölçekteki derecelendirme 5'li Likert derecelendirmesine uygun olacak tarzda (1: Kesinlikle Katılmıyorum; 5: Kesinlikle Katıliyorum) uygulanmıştır.

Araştırma evrenini Balıkesir ilinde bulunan konaklama işletmeleri çalışanları oluşturmaktadır. Balıkesir'de bulunan konaklama işletmelerindeki çalışan sayısının tespitine yönelik olarak herhangi bir veriye rastlanmadığından, yatak sayısının hesaplanması ile çalışan sayısına ulaşmak hedeflenmiştir. Pelit (2008: 145), Türkiye'de ortalama olarak yatak başına 0,35 çalışan düştüğünü ifade etmektedir. Kültür ve Turizm Bakanlığı'ndan elde edilen verilere göre 31.01.2019 tarihi itibariyle Balıkesir'deki 109 işletme ve yatırım belgeli tesiste 10.580 yatak bulunmaktadır (KTB, 2019). Bu kapsamda çalışan sayısı yaklaşık olarak 4.753 $(=10.580 * 0,35)$ olmaktadır. Evrenin tamamına ulaşmak mümkün olmayacağından, araştırmada kolayda örnekleme tekniğine göre örneklem alınma yoluna gidilmiştir. Bu kapsamda, \%95 güvenirlik düzeyinde, örneklem büyüklüğünün 357 olmas1 gerekmektedir (Sekaran, 2003: 294). 
Anket formu 2018 yılının Mayıs ve Haziran aylarını kapsayacak şekilde 400 çalışan ile ve yüz yüze görüşülerek uygulanmıştır. Geriye dönen 323 anket formundan 300 tanesinin değerlendirmeye uygun olduğu anlaşı1mış ve bu veriler üzerinden değerlendirmeler yapılmıştır. Veriler, IBM SPSS 21.0 ve Lisrel 8.80 paket programları aracılığıyla analiz edilmiştir. Çalışanların demografik özellikleri frekans ve yüzde dağılımları verilerek değerlendirilmiştir. Güvenirlik, Cronbach's Alpha katsayısı ve madde-bütün korelasyonları hesaplanarak; geçerlik çalışmaları ise yapı geçerliği ekseninde yapılmıştır. Değişkenleri daha sağlıklı bir şekilde belirlemek amacıyla, açıklayıcı faktör analizi (AFA) ve doğrulayıcı faktör analizi (DFA) yapılmıştır. Çalışanların LÜE algısı düzeyini hesaplayabilmek için ölçek ortalaması hesaplanmış; bağımsız değişkenlerin bağımlı değişken üzerindeki etkisini görebilmek amacıyla ikili lojistik regresyon analizi yapılmıştır.

Lojistik regresyon analizi, son dönemlerde özellikle sosyal bilimler yazınında giderek daha fazla kullanılan bir yöntemdir. Bu analiz türü, incelenen değişkenlerin evet-hayır, var-yok, olumlu-olumsuz, başarılı-başarısız şeklinde sürekli olmayan, bir diğer ifadeyle kategorik verileri içermesi (Tabachnick ve Fidell, 2007: 437; Can, 2018: 293) durumunda, bağımlı değişken ile bağımsız değișken/değișkenler arasındaki neden-sonuç ilişkilerinin incelenmesinde, diğer analizlere göre daha elverişli olmasının avantajı ile önemli bir yere sahiptir (Peng ve So, 2002: 33; Field, 2009: 265).

Lojistik regresyonu analizi, bağımsız değişkenlerin dağılımına ilişkin herhangi bir varsayımın karşılanmasını gerektirmez (Çokluk, 2010: 1368). Ancak yine de bağımsız değişkenler arasında yüksek düzeyde bir ilişki bulunmaması, uç değerlerin olmaması ve en az aralık ölçeğinde sürekli olan bağımsız değişkenler ile bağımlı değişkenin logit dönüşümü arasında doğrusal bir ilişkinin olması, karşılanması gereken varsayımlardır (Can, 2018: 309-313).

Lojistik regresyon analizinin üç ayrı çeşidi olmakla birlikte bu araştırmada "ikili lojistik regresyon analizi" kullanılacaktır. Zira bağımlı değişken, iki seçenekli bir kategorik değişken ise "İkili Lojistik Regresyon Analizi (Binary Logistic Regression Analysis)" kullanılmalıdır (Çokluk, 2010: 1362). Bunun için öncelikle bağımlı değişkenin iki sınıflı bir kategorik bir değişken olması gerekmektedir. Bu nedenle ilk olarak bağımlı değişken olan LÜE'nin alt boyutları iki sonuçlu hale getirilmiştir. Ordun ve Aktaş (2014)'ın izlediği yönteme uygun şekilde, her bir boyutta ortaya çıkan ortalamanın bir standart sapma üstü puan alanlar, yüksek LÜE (alt boyutu) algısına sahip çalışanlar (iç grup); bir standart sapma altı puan alanlar ise düşük algıya sahip olanlar (dış grup) olarak belirlenmiştir. Buna uygun olarak da dış grupta olan çalışanlar 0 (sıfir) ile iç grupta olanlar 1 (bir) ile kodlanmıştır. Buna göre diş grupta bulunan çalışanlar referans kategoriyi, iç grupta yer alanlar ise hedef kategoriyi oluşturmaktadır. Bu analizlerde yer alacak bağımsız değişkenler ise şu şekildedir:

- Cinsiyet (0: Kadın; 1: Erkek)

- Medeni Hal (0: Evli; 1: Bekar)

- Yaş (0: 29 ve altı; 1: 30 ve üstü)

- Eğitim Seviyesi (1: İlköğretim/ Ortaöğretim; 2: Önlisans; 3: Lisans)

- Günlük Çalışma Süresi (0: 0-8 Saat; 1: 8 saatten fazla)

- Aylik Gelir (0: 0 - 2800 TL; 1: 2801 TL ve üstü)

- Sektör Deneyimi (1: 1 yıldan az; 2: 1-5 y1l; 3: 6 - 10 yıl; 4: 11 yıl ve üzeri)

- İşletme Deneyimi (1: 1 yıldan az; 2: 1-5 Y11; 3: 6 yıl ve üzeri)

- Turizm Eğitimi Seviyesi (1: Almayan; 2: Ortaöğretim Düzeyinde; 3: Önlisans Düzeyinde; 4: Lisans Düzeyinde)

- Çalışma Biçimi (0: Tüm yıl çalışan; 1: Sezonluk çalışan)

Lojistik regresyon analizi sonucunu gösterecek tablolardaki B değeri, bağımsız değişkenlerin, bağımlı değişken üzerindeki pozitif veya negatif etkisini gösteren regresyon katsayısıdır. Bu değerin negatif işaretli olması olayın görülme olasılığını azaltırken, pozitif işaret bu konuda bir artış yaşanacağına delildir. Exp (B) değeri ise diğer değişkenler sabitken herhangi bir bağımsız değişkende görülecek bir birimlik artışın olayın görülme olasılığındaki artışı belirtmektedir (Moital vd., 2009: 353).

\section{BULGULAR}

Araştırmaya katılan bireylerin demografik özellikleri Tablo 1'de sunulmuştur. Buna göre, katılımcılar ağırlıklı olarak erkek (\%63,3), bekar (\%58,7), 21-29 yaş aralığında (\%51), ilköğretim/ortaöğretim düzeyinde eğitime sahip $(\% 45,3), 0-2800$ TL gelire sahip $(\% 83,7)$ ve tüm y1l çalışan $(\% 77)$ konumundadır. \%69,3 oranında günlük 8 saatten fazla çalışan katılımcıların yarıdan biraz fazlasının 1-5 yıl aralığında hem sektör deneyimi hem de işletme deneyimi bulunmaktadır. Ayrıca katılımcıların yarıya yakını $(\% 48,3)$ herhangi düzeyde bir turizm eğitimi almamıştır. 
Tablo 1. Katılımcıların demografik özelliklerine göre dağılımı

\begin{tabular}{|c|c|c|c|c|c|c|c|}
\hline \multicolumn{2}{|c|}{ Değişkenler } & \multirow{2}{*}{$\begin{array}{c}\mathbf{n} \\
110\end{array}$} & \multirow{2}{*}{$\begin{array}{c}\% \\
36,7\end{array}$} & \multicolumn{2}{|c|}{ Değişkenler } & \multirow{2}{*}{$\begin{array}{c}\mathbf{n} \\
41\end{array}$} & \multirow{2}{*}{$\begin{array}{c}\% \\
13,7\end{array}$} \\
\hline Cincivet & Kadın & & & \multirow{4}{*}{$\begin{array}{c}\text { Sektör } \\
\text { Deneyimi }\end{array}$} & 1 yıldan az & & \\
\hline Cinsiyed & Erkek & 190 & 63,3 & & $1-5 \mathrm{yll}$ & 155 & 51,7 \\
\hline \multirow{2}{*}{ Medeni Hal } & Evli & 124 & 41,3 & & $6-10 \mathrm{yıl}$ & 64 & 21,3 \\
\hline & Bekar & 176 & 58,7 & & 11 yıl ve üzeri & 40 & 13,3 \\
\hline \multirow{4}{*}{ Yaş } & $16-20$ & 28 & 9,3 & \multirow{3}{*}{$\begin{array}{l}\text { İşletme } \\
\text { Deneyimi }\end{array}$} & 1 yıldan az & 75 & 25 \\
\hline & $21-29$ & 153 & 51 & & $1-5$ yıl & 173 & 57,7 \\
\hline & $30-39$ & 92 & 30,7 & & 6 yıl ve üzeri & 52 & 17,3 \\
\hline & $40-49$ & 27 & 9 & \multirow{4}{*}{$\begin{array}{l}\text { Turizm Eğitimi } \\
\text { Seviyesi }\end{array}$} & Almayan & 145 & 48,3 \\
\hline \multirow{3}{*}{$\begin{array}{l}\text { Eğitim } \\
\text { Seviyesi }\end{array}$} & $\begin{array}{l}\text { illköğretim/ } \\
\text { Ortaöğretim }\end{array}$ & 136 & 45,3 & & $\begin{array}{l}\text { Ortaöğretim } \\
\text { Düzeyinde }\end{array}$ & 30 & 10 \\
\hline & Önlisans & 77 & 25,7 & & $\begin{array}{c}\text { Önlisans } \\
\text { Düzeyinde }\end{array}$ & 51 & 17 \\
\hline & Lisans & 87 & 29 & & $\begin{array}{c}\text { Lisans } \\
\text { Düzeyinde }\end{array}$ & 74 & 24,7 \\
\hline \multirow{2}{*}{$\begin{array}{c}\text { Günlük } \\
\text { Çalışma Süresi }\end{array}$} & $0-8$ saat & 92 & 30,7 & \multirow{2}{*}{ Çalışma Biçimi } & $\begin{array}{l}\text { Tüm yıl } \\
\text { çalışan }\end{array}$ & 231 & 77 \\
\hline & $\begin{array}{c}8 \text { saatten } \\
\text { fazla }\end{array}$ & 208 & 69,3 & & $\begin{array}{l}\text { Sezonluk } \\
\text { çalışan }\end{array}$ & 69 & 23 \\
\hline \multirow[b]{2}{*}{ Aylık Gelir } & $0-2800 \mathrm{TL}$ & 251 & 83,7 & & & & \\
\hline & $\begin{array}{l}2801 \text { TL ve } \\
\text { üstü }\end{array}$ & 49 & 16,3 & & & & \\
\hline
\end{tabular}

Araştırmada kullanılan ölçeğe ait güvenirlik düzeyini ölçmek amacıyla içsel tutarlılık analizi yapılmış ve madde-bütün korelasyon değerlerine bakılmıştır. İç tutarlılık düzeyinin belirlenmesi amacıyla uygulanan Cronbach's Alpha $(\alpha)$ testi sonucunda LÜE ölçeğine ait $\alpha=0,92$ olarak tespit edilmiştir. Madde-bütün korelasyon değerleri ise eşik değer olan 0,30'un (Şencan, 2005: 112) üstünde; 0,52 ile 0,77 arasında değişmektedir. Bu sonuçlar ölçeğin yüksek derecede güvenirliğe sahip olduğunu ortaya koymaktadır.

Ölçeğin yapı geçerliğini kontrol etmek için açıklayıcı ve doğrulayıcı faktör analizi yapılmıştır. Aynı zamanda turizm sektöründe yapılmış çalışmaların ve bu analizlerin nadiren yapılmış olması nedeniyle analizlerin gerekli olduğu düşünülmektedir. Verilerin açıklayıcı faktör analizine uygunluğunu ortaya koyan Kaiser-Meyer-Olkin $(\mathrm{KMO}=0,890)$ katsayısı ve Barlett küresellik testi $\left(\mathrm{x}^{2}=1827,144 ; \mathrm{p}<0,01\right)$ değerleri yeterli düzeydedir. Varimax rotasyonu ile yapılan açıklayıcı faktör analizi sonucunda faktör yapısını bozduğu tespit edilen üç ifade (7-8-12) ölçekten çıkarılmıştır. Bu işlemlerin ardından özdeğeri 1'den büyük ve toplam varyansın \%80,9'unu açıklayan üç faktörlü bir yapı elde edilmiştir (Tablo 2). 
Tablo 2. LÜE Ölçeğine İlişkin Açıklayıcı Faktör Analizi

\begin{tabular}{|c|c|c|c|c|c|c|}
\hline Ifadeler & 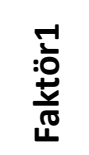 & 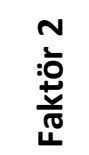 & 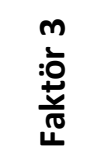 & 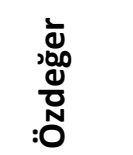 & 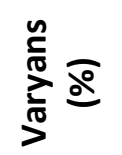 & ૪ \\
\hline \multicolumn{7}{|c|}{ Faktör 1: Etki $(\bar{X}=4,14 ;$ S.S. $=0,64)$} \\
\hline ifade 1 & ,889 & & & \multirow{3}{*}{2,47} & \multirow{3}{*}{27,7} & \multirow{3}{*}{87} \\
\hline ifade 2 & ,851 & & & & & \\
\hline Ifade 3 & ,780 & & & & & \\
\hline \multicolumn{7}{|c|}{ Faktör 2: Mesleki Saygı ( $\bar{X}=4,12 ;$ S.S. $=0,81$ ) } \\
\hline Ifade 10 & & 830 & & \multirow{3}{*}{2,43} & \multirow{3}{*}{27} & \multirow{3}{*}{, 87} \\
\hline Ifade 9 & & ,785 & & & & \\
\hline ifade 11 & & 779 & & & & \\
\hline \multicolumn{7}{|c|}{ Faktör 3: Bağlılık ( $\bar{X}=4,06 ;$ S.S. $=0,87)$} \\
\hline ifade 4 & & & 827 & \multirow{3}{*}{2,37} & \multirow{3}{*}{26,2} & \multirow{3}{*}{,88 } \\
\hline ifade 6 & & & 778 & & & \\
\hline ifade 5 & & & ,771 & & & \\
\hline & \multicolumn{4}{|c|}{ Toplam Açıklanan Varyans (\%) } & \multicolumn{2}{|c|}{80,9} \\
\hline \multicolumn{5}{|c|}{ Ölçeğin Tamamı için Cronbach's Alpha } & \multicolumn{2}{|c|}{91} \\
\hline \multicolumn{7}{|c|}{ Varimax Rotasyonlu Temel Bileşenler Faktör Analizi } \\
\hline \multicolumn{7}{|c|}{ KMO: ,890; Barlett Küresellik testi=1827,144; $p<0,01$} \\
\hline
\end{tabular}

Orijinal ölçek, dört boyutlu bir yapıyı temsil etmesine rağmen burada üç faktörlü bir yapı ortaya çıkmıştır. Esasında buna uygun olarak Kaşlı ve Seymen (2010)'de otel çalışanlarının LÜE'yi üç boyut altında algıladıklarını tespit etmişlerdir. $\mathrm{Bu}$ nedenle ortaya çıkan üç faktörlü yapının kabul edilebilir olduğu söylenebilir. Ayrıca kültürel farklılıkların yanı sıra çeviri işlemleri sırasında bazı kelimelerin ve cümle yapılarının değişebilmesi, çevirisi yapılan ölçeğin, orijinal ölçek ile benzerliğini azaltabilmekte, bu da faktör yapısının değişmesine yol açabilmektedir (Kwon ve Lim, 2007: 107). Aynı zamanda katılımcıların eğitim seviyesi ya da okuma ve anlama kapasiteleri gibi durumlar da ankete verilen cevapları etkileyerek faktör yapısının değişmesine kapı aralayabilmektedir.

Tablo 2'de yer alan sonuçlara göre birinci faktöre ait öz değerin 2,47; varyansı açıklama oranının \%27,7 olduğu görülmektedir. Bu faktör altında lider ile üye arasındaki yakınlığa dayanan ya da arkadaşlık temelinde gelişen ilişkileri içeren ifadeler yer aldığından "etki" olarak isimlendirilmiştir. İkinci faktörün öz değeri 2,43; varyansı açıklama oranı \%27'dir. Bu faktör kişilerin sahip oldukları saygınlık derecesi ile ilgili ifadelere sahip olduğundan "mesleki saygı" adını almıştır. Üçüncü faktörün öz değeri 2,37; varyansı açıklama oranı \%26,2'dir. Bu faktör ikilinin birbirine ne derece sadık olduğunu ölçen ifadeleri içerdiğinden "bağlılık" ismini almıştır.

Ölçek geneli ortalama söz konusu olduğunda ise yüksek bir ortalama karşımıza çıkmaktadır $(4,12 \pm 0,67)$. $\mathrm{Bu}$ sonuca göre otel çalışanlarının, liderleri ile yüksek bir etkileşim içerisinde olduklarını düşündükleri söylenebilmektedir.

Ölçeğe açıklayıcı faktör analizi (AFA) yapıldıktan sonra doğrulayıcı faktör analizi (DFA) yapılmıştır. DFA, önceden tanımlı bir yapının bir model olarak doğrulanıp doğrulanmadığını analiz eden bir testtir. Bir başka ifadeyle DFA, AFA'da ortaya çıkan faktör yapısının doğrulanmasına aracılık etmektedir (Çokluk vd., 2014: 275). Bu aşamada, ölçeğe ait alt boyutların da temsil derecesini belirleyebilmek maksadıyla ikinci düzey DFA tercih edilmiştir. Analiz sonrasında uyum iyiliği indekslerinin ( $\chi 2$ /sd: 2,10; RMSEA: 0,061; SRMR: 0,025; GFI: 0,97; AGFI: 0,93; NFI: 0,99;CFI: 0,99) yeterli düzeyde olduğu (Schermelleh-Engel vd., 2003: 52) görülmüştür. $\mathrm{Bu}$ sonuçlara göre AFA sonucunda ortaya çıkan üç faktörlü yapı, DFA aracılığıyla doğrulanmıştır. İkinci düzey DFA sonucunda ifadelerin ve boyutlar arasındaki ilişkinin derecesini gösteren yük değerleri Tablo 3'de görülmektedir. 
Tablo 3. LÜE Ölçeğine İlişkin İkinci Düzey DFA Sonuçlarının Standardize Yük Değerleri

\begin{tabular}{|c|c|c|c|c|}
\hline \multicolumn{2}{|c|}{ Örtük değişkenler } & $\begin{array}{l}\text { Standardize } \\
\text { Yükler }\end{array}$ & $\begin{array}{c}\text { Gözlenen } \\
\text { Değişkenler }\end{array}$ & $\begin{array}{l}\text { Standardize } \\
\text { Yükler }\end{array}$ \\
\hline \multirow{9}{*}{ 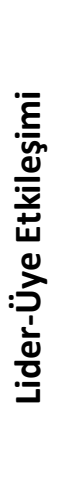 } & \multirow{3}{*}{ Etki } & \multirow{3}{*}{0,65} & ifade1 & 0,59 \\
\hline & & & ifade2 & 0,67 \\
\hline & & & ifade3 & 0,69 \\
\hline & \multirow{3}{*}{ Bağlılık } & \multirow{3}{*}{0,92} & ifade4 & 0,83 \\
\hline & & & ifade5 & 0,82 \\
\hline & & & ifade6 & 0,81 \\
\hline & \multirow{3}{*}{ Mesleki Saygı } & \multirow{3}{*}{0,91} & ifade9 & 0,75 \\
\hline & & & Ifade10 & 0,77 \\
\hline & & & Ifade11 & 0,76 \\
\hline
\end{tabular}

Araştırmanın bu aşamasından sonra, araştırmada ele alınan demografik değişkenlerin, çalışanların lider ile üye arasındaki etkileşimin alt boyutları açısından iç grupta yer alma ihtimalleri üzerinde ne kadar etkisi olduğunu ortaya koymak amacıyla ikili lojistik regresyon analizi yapılmıştır. Öncelikle analiz için gerekli olan varsayımların kontrolü gerçekleştirilmiştir. Öncelikle bağımsız değişkenler arasında yüksek düzeyli bir korelasyon olmadığı gözlenmiştir. Ardından diğer varsayım olan en az aralık ölçeğinde sürekli olan bağımsız değişkenler ile bağımlı değişkenin logit dönüşümü arasında doğrusal bir ilişkinin olmaması varsayımının, bu araştırmada sürekli bağımsız değişkenin olmaması nedeniyle karşılanması gerekmediği öngörülmüştür. Son olarak uç değerlerin kontrolü üç analiz için de ayrı ayrı yapılmıştır. Buna göre etki boyutu açısından uç değerin olmadığı gözlenmiş, mesleki saygı ve bağl11ık boyutu açısından da uç değerlerin olduğu anketler veri setinden çıkarılmış ve analize bu şekilde devam edilmiştir (Can, 2018: 309-312).

Tablo 4. Etki Boyutu Açısından Lojistik Regresyon Modelindeki Değişkenler ve Katsayıları

\begin{tabular}{|c|c|c|c|c|c|}
\hline & B (sh) & Wald & df & Sig. & $\operatorname{Exp}(B)$ \\
\hline Cinsiyet(1) &,$- 255(, 51)$ & 251 & 1 & ,617 & ,775 \\
\hline Medeni Hal(1) & ,498 (,61) & ,656 & 1 & ,418 & 1,645 \\
\hline Yaş(1) & ,314 (,66) & ,220 & 1 & 639 & 1,368 \\
\hline Eğitim Durumu & ,107 (,44) & ,057 & 1 & 811 & 1,113 \\
\hline Aylık Gelir(1) & $1,889(, 93)^{*}$ & 4,119 & 1 & 042 & 6,612 \\
\hline Çalışma Biçimi(1) & ,335 (,57) & 343 & 1 & ,558 & 1,398 \\
\hline Günlük Çalışma Süresi(1) &,$- 292(, 53)$ & ,295 & 1 & ,587 & ,747 \\
\hline Turizm Eğitimi &,$- 526(, 31)$ & 2,729 & 1 & 099 & ,591 \\
\hline İşletme Deneyimi &,$- 491(, 53)$ & 838 & 1 & 360 & ,612 \\
\hline Sektör Deneyimi & $1,382(, 51)^{* *}$ & 7,210 & 1 & ,007 & 3,984 \\
\hline Sabit & $-1,631(1,4)$ & 1,337 & 1 & 248 & 196 \\
\hline Varyans Açıklama Oranı & \multicolumn{5}{|c|}{ Cox ve Snell=\%23; Nagelkerke=\%31 } \\
\hline Ki-kare & & & & & 27,957 \\
\hline Hosmer \&Lemeshow & & & & & 277 \\
\hline Omnibus sig. & & & & & ,007 \\
\hline
\end{tabular}

B: Beta; sh: Standart Hata; ${ }^{*} p<0,05 ;{ }^{* *} p<0,01$

Etki boyutu açısından iç grupta yer alma ihtimali üzerinde demografik değişkenlerin ne kadar etkisi olduğunu ortaya koymak amaciyla yapılan analiz sonucunda, regresyon modelinin istatistiksel olarak anlamlı olduğu görülmüştür $\left(x^{2}=27,957 ; p<0,01\right)$. Hosmer ve Lemeshow Uyum İyiliği Testinin de anlamlı olmamas1 (p>0,05), modelin anlamlılığına katkı yapan bir diğer sonuçtur. Modelin Nagelkerke $\mathrm{R}^{2}$ katsayısına göre iç grupta yer alma üzerindeki değişimin \%31'ini açıkladığı ve genel olarak katılımcıların \%66,4'ünü doğru kategorilerde sınıflandırdığı söylenebilmektedir. Sonuçlar Tablo 4'de görülmektedir. 
Elde edilen sonuçlara göre çalışanların etki boyutu açısından iç grupta yer alam ihtimali ile aylık gelir ve sektör deneyimi ilişkilidir. Aylık gelir, 1,889 B değeri ve 6,612 Exp (B) değeri ile en fazla etkisi olan bağımsız değişken konumundadır. Bu durum, diğer bağımsız değişkenler sabit kaldığında aylık gelirdeki bir birimlik artışın etki boyutu açısından iç grupta yer alma ihtimalini yaklaşık altı kat artırdığı anlamına gelmektedir. Bir başka ifadeyle aylık geliri daha yüksek olanların (burada 2801 TL ve üstü) iç grupta yer alma ihtimalleri çok daha yüksektir. Sektör deneyiminin B değeri 1,382 ve Exp (B) değeri 3,984'dür. Bu da benzer şekilde sektör deneyiminin artması ile etki boyutu açısından iç grupta yer alma ihtimalini yaklaşık dört kat artırmaktadır.

Mesleki Saygı boyutu açısından iç grupta yer alma ihtimali üzerinde demografik değişkenlerin ne kadar etkisi olduğunu ortaya koymak amacıyla yapılan analiz sonucunda ortaya çıkan regresyon modelinin istatistiksel olarak anlamlı olduğu görülmüştür $\left(x^{2}=62,704 ; p<0,01\right)$. Hosmer ve Lemeshow Uyum İyiliği Testinin de anlamlı olmaması $(p>0,05)$, modelin anlamlılı̆̆ına katkı yapan bir diğer sonuçtur. Model Nagelkerke $\mathrm{R}^{2}$ katsayısı ile iç grupta yer alma üzerindeki değişimin \%41'ini açıklamış, genel olarak katılımcıların \%77,5'ini doğru kategorilerde sınıflandırmıştır. Sonuçlar Tablo 5'de görülmektedir.

Tablo 5. Mesleki Saygı Boyutu Açısından Lojistik Regresyon Modelindeki Değişkenler ve Katsayıları

\begin{tabular}{|c|c|c|c|c|c|}
\hline & B (sh) & Wald & df & Sig. & $\operatorname{Exp}(B)$ \\
\hline Cinsiyet(1) &,$- 694(, 44)$ & 2,419 & 1 &, 120 & ,449 \\
\hline Medeni Hal(1) &,$- 067(, 50)$ & ,018 & 1 & ,893 & ,935 \\
\hline Yaş(1) & $-1,818(, 59)^{* *}$ & 9,363 & 1 & ,002 & ,162 \\
\hline Eğitim Durumu &,$- 232(, 37)$ & ,376 & 1 &, 540 & ,793 \\
\hline Aylık Gelir(1) &, $034(, 05)$ & ,008 & 1 & 924 & 950 \\
\hline Çalışma Biçimi(1) & $-1,393(, 51)^{* *}$ & 7,356 & 1 &, 007 & ,248 \\
\hline Günlük Çalışma Süresi(1) &,$- 042(, 46)$ & ,008 & 1 & ,928 & ,959 \\
\hline Turizm Eğitimi &,$- 069(, 28)$ & ,062 & 1 & ,804 & ,933 \\
\hline İşletme Deneyimi & $-1,602(, 53)^{* *}$ & 9,174 & 1 & ,002 & ,201 \\
\hline Sektör Deneyimi & $2,083(, 51)^{* *}$ & 16,394 & 1 &, 000 & 8,032 \\
\hline Sabit & $1,276(1,2)$ & 1,102 & 1 & ,293 & 3,581 \\
\hline Varyans Açıklama Oranı & \multicolumn{5}{|c|}{ Cox ve Snell=\%30; Nagelkerke=\%41 } \\
\hline Ki-kare & & & & & 62,704 \\
\hline Hosmer \&Lemeshow & & & & & 924 \\
\hline Omnibus sig. & & & & & 000 \\
\hline
\end{tabular}

B: Beta; sh: Standart Hata; ${ }^{* *} p<0,01$

Tablo 5'de yer alan sonuçlara göre, çalışanların mesleki saygı boyutu açısından iç grupta yer alma ihtimali ile yaş, çalışma biçimi, işletme deneyimi ve sektör deneyimi anlamlı ilişkilere sahiptir. Yaş ve işletme deneyimi değişkenleri bakımından, değişkenin değerinin bir birim artması ile mesleki saygı algısının düştüğü görülmektedir. Buna göre yaşı 29 ve altı olanların, 30 yaş ve üstüne göre mesleki saygı algıları yaklaşı altı kat $(1 / 0,162)$; işletme deneyiminde yaşanan bir birimlik azalma ise mesleki saygı algısını yaklaşık beş kat $(1 / 0,201)$ artırmaktadır. Çalışma biçimi değişkeni açısından da yine benzer bir sonuç görülmektedir. Buna göre sezonluk çalışanların, tüm yıl çalışanlara kıyasen, mesleki saygı algılarının daha düşük olduğu söylenebilmektedir. Ya da buna tersinden bakarsak, tüm yıl çalışanlarda mesleki saygı algısı, diğer gruba göre yaklaşık dört kat $(1 / 0,248)$ daha fazladır. Sektör deneyimi ise bir birimlik artışı ile mesleki saygı algısını sekiz kat artırmaktadır.

Bağl11ık boyutu açısından iç grupta yer alma ihtimali üzerinde demografik değişkenlerin ne kadar etkisi olduğunu ortaya koymak amacıyla yapılan analiz sonucunda ortaya çıkan regresyon modelinin istatistiksel olarak anlamlı olduğu görülmüştür $\left(\mathrm{x}^{2}=40,152 ; \mathrm{p}<0,01\right)$. Hosmer ve Lemeshow Uyum İyiliği Testinin de anlamlı olmaması $(\mathrm{p}>0,05)$, modelin anlamlılığına katkı yapan bir diğer sonuçtur. Model Nagelkerke $\mathrm{R}^{2}$ katsayısı ile iç grupta yer alma üzerindeki değişimin \%28' ini açıklamış, genel olarak katılımcıların \%69,4'ünü doğru kategorilerde sınıflandırmıştır (Tablo 6). 
Tablo 6. Bağlılık Boyutu Açısından Lojistik Regresyon Modelindeki Değişkenler ve Katsayıları

\begin{tabular}{|c|c|c|c|c|c|}
\hline & B (sh) & Wald & df & Sig. & $\operatorname{Exp}(B)$ \\
\hline Cinsiyet(1) &,$- 310(, 39)$ & ,609 & 1 & ,435 & ,734 \\
\hline Medeni Hal(1) &,$- 164(, 45)$ & 121 & 1 & ,717 & ,848 \\
\hline Yaş(1) &,$- 844(, 53)$ & 2,465 & 1 & ,116 & ,430 \\
\hline Eğitim Durumu &,$- 840(, 35)^{*}$ & 5,745 & 1 & ,017 & ,432 \\
\hline Aylık Gelir(1) &, $544(, 67)$ & ,635 & 1 & ,426 & 1,723 \\
\hline Çalışma Biçimi(1) &,$- 413(, 41)$ & ,903 & 1 & ,341 & ,661 \\
\hline Günlük Çalışma Süresi(1) &,$- 0431(, 36)$ & ,006 & 1 & 940 & 970 \\
\hline Turizm Eğitimi & ,190 (,25) &, 572 & 1 & ,449 & 1,209 \\
\hline İşletme Deneyimi & $-1,304(, 43)^{*}$ & 5,317 & 1 & ,021 & ,356 \\
\hline Sektör Deneyimi & $1,745(, 41)^{* *}$ & 14,477 & 1 & ,000 & 5,728 \\
\hline Sabit & $1,276(1,0)$ & 1,367 & 1 & ,242 & 3,520 \\
\hline Varyans Açıklama Oranı & \multicolumn{5}{|c|}{ Cox ve Snell=\%20; Nagelkerke=\%28 } \\
\hline Ki-kare & & & & & 40,152 \\
\hline Hosmer \&Lemeshow & & & & & ,146 \\
\hline Omnibus sig. & & & & & 000 \\
\hline
\end{tabular}

B: Beta; sh: Standart Hata; ${ }^{*} p<0,05 ;{ }^{* *} p<0,01$

Tablo 6'da yer alan sonuçlara göre, bağl1lık boyutu üzerinde eğitim durumu, işletme deneyimi ve sektör deneyimi anlamlı etkilere sahiptirler. Buna göre eğitim durumu bir birim azaldıkça bağlılık algısı yaklaşık iki buçuk kat $(1 / 0,432)$ artmaktadır. İşletme deneyimi bir birim azaldıkça bağlılık algısı yaklaşık üç kat $(1 / 0,356)$ artmaktadır. Sektör deneyimi söz konusu olduğunda ise sektör deneyimindeki artış, bağlılık algısını 5,7 kat artırmaktadır.

\section{TARTIŞMA VE SONUÇ}

$\mathrm{Bu}$ araştırmada, konaklama işletmelerinde görev yapan alt düzey çalışanların LÜE algı düzeyini ortaya koymak amaçlanmıştır. Elde edilen sonuçlara göre çalışanlar, hem genel olarak hem de alt boyutları itibariyle yüksek düzeyde LÜE algısı taşımaktadır. Buna göre çalışanların, liderleri ile yüksek düzeyli bir etkileşim içerisinde oldukları dile getirilebilir. Bu durum çalışanların yüksek iş tatminine ulaşabilmesi, daha motive olmuş bir şekilde çalışabilmesi ve daha yüksek performans düzeyine ulaşabilmesi gibi olumlu sonuçlara da yol açacağından gerekliliği yüksek düzeyde olan önemli bir husustur. Bu bakımdan konaklama işletmelerinde bunun sağlanabilmiş olması bir başarı olarak değerlendirilebilir.

LÜE'nin alt boyutları itibari ile ortalamalara bakıldığında genel ortalamaya benzer şekilde yüksek ortalamalar göze çarpmaktadır. En yüksek ortalama etki boyutunda ortaya çıkmıştır. Etki boyutu, hatırlanacağı üzere, taraflar arasındaki iş ya da profesyonel değerlerden daha çok kişiler arasındaki arkadaşlık ilişkilerini konu edinen boyuttur. Bu boyuttaki ortalamanın yüksek olması çalışanların liderlerini sosyal olarak beğendikleri ve ilişkilerinin kuvvetli olduğu şeklinde yorumlanabilir. Hem genel LÜE'nin hem de alt boyutlarının yüksek düzeyde ortalamalara sahip olması ile çalışanların kendilerini daha çok iç grupta yer alan bireyler olarak algıladıkları ifade edilebilir. Bu, liderlerin daha büyük bir iç gruba sahip oldukları şeklinde yorumlanabilir ve yazında bu yönde yapılan öneri ile örtüşmektedir.

Çalışanların demografik özellikleri ile LÜE ilişkisini, hangi grubun daha yüksek ya da düşük ortalamaya sahip olduğunu anlayacak tarzda ele alan çalışmalar bulunmaktadır. Örneğin, cinsiyet bakımından hangi grubun daha yüksek algı düzeyine sahip olduğunu ortaya koyan çalışmalara rastlanmaktadır (bkz. Tanrıverdi ve Kahraman, 2016; Demirci, 2017). Ancak bu çalışmalarda herhangi bir demografik değişkenin herhangi bir grubunda yer almanın, iç grupta yer alma ihtimali üzerinde ne kadar etkisi olduğu hakkında bir inceleme ya da bilgi görülmemektedir. Bu çalışmanın diğer amacının da zaten bu boşluğu doldurmaya çalışmak olduğu belirtilmişti.

Faktör analizi sonucunda LÜE ölçeğinde ortaya çıkan alt boyutlara ayrı ayrı ikili lojistik regresyon analizi yapılarak, iç grupta yer alma ihtimali üzerinde hangi değişkenin ne derece etkili olduğu incelenmiştir. Öncelikle etki boyutunu incelersek, aylık gelir ve sektör deneyimi değişkenlerinin iç grupta yer alma ihtimali 
üzerinde etkili olduğu görülmektedir. Sonuçlara göre aylık gelirin 2801 TL ve üstünde olması iç grupta yer alma ihtimalini yaklaşık olarak altı kat artırmaktadır. Bu, etki boyutu itibariyle daha yüksek gelir grubunda yer almak anlamındadır ve çalışanın lideri ile daha yüksek bir etkileşim içerisine girebilmesine zemin hazırlamaktadır. Sektör deneyimi söz konusu edildiğinde ise benzer şekilde deneyimin artışı ile iç grupta yer alma ihtimalinin yaklaşık olarak dört kat arttı̆̆ tespit edilmiştir.

Gelirin ve sektör deneyiminin artması ile LÜE'nin de artması konusunda şunlar söylenebilir. Denebilir ki, geliri artan bir çalışan -tabiri caizse- işyerinde kafası rahat bir şekilde çalışabilecektir. Bu ise çalışanın yönetsel talimatları anlama ve yerine getirme konusunda daha hazır ve istekli olmasina zemin hazırlayabilecektir. Sektör deneyimindeki artış ise çalışanlara iş prosedürlerini daha kolay anlayabilme, iş akışını hızlandırabilme gibi yetiler kazandırabilmektedir. Liderlerin de zaten bu tarz çalışanlarla beraber iş görebilmeyi daha çok arzulaması, lider-üye etkileşimini artıran bir unsur olarak ele değerlendirilebilir.

Mesleki saygı boyutu açısından, iç grupta yer alma ihtimali ile yaş, çalışma biçimi, işletme deneyimi ve sektör deneyimi anlamlı ilişkilere sahiptir. Buna göre yaş ve işletme deneyimi azaldıkça mesleki saygı algısı artmaktadır. Sektör deneyimi ise artışı ile mesleki saygı algısını artırmaktadır. Bunula birlikte tüm yıl çalışanlardaki mesleki saygı algısının sezonluk çalışanlara göre daha yüksek olduğu da söylenebilmektedir.

Yaş konusu ile ilgili olarak, yaşça büyük çalışanların, özellikle 40'lı ve üstündeki yaş diliminde, davranış değişikliği göstermede daha çok zorlandıkları, daha az eğitilebilir oldukları ve yaratıcılık ve üretkenlik gibi faktörler açısından daha az performansa sahip oldukları genel bir kabul olarak ifade edilmektedir (Smith ve Harrington, 1994: 804). Bütün bunlar da lider ile üye arasındaki etkileşimi olumsuz yöne etkileyebilecek unsurlar olarak değerlendirilebilir. Bu nedenle yaşça daha küçük çalışanların lider ile daha yüksek etkileşim gösterecekleri şeklindeki sonucun yazın ile uyumlu olduğu da ifade edilebilir. Ayrıca daha önce yapılmış araştırmaların sonuçları, yaş ile LÜE arasında farklı farklı ilişkileri ortaya çıkarmıştır. Örneğin Wang (2016) iki değişken arasında zayıf bir ilişki tespit ederken (r=0,12); Brouer vd. (2009) herhangi bir ilişki olmadığını rapor etmektedir. Epitropaki ve Martin (1999) ise lider ile üye arasındaki yaş farkının artması ile ikili arasındaki etkileşimin artacağına değinmektedir.

İşletme deneyimi ile LÜE arasındaki ilişki mevzuu bahis olduğunda farklı sektörlerde araştırmalar yürüten Wayne vd. (1997), Wayne vd. (2002), Brouer vd. (2009) ile Loi vd. (2014), işletme deneyiminin genel LÜE üzerinde etkisi olmadığını tespit etmişlerdir. Bu araştırmanın sonuçları ise konaklama işletmeleri çalışanlarının işletme deneyimi arttıkça çalışanın lidere karşı olan mesleki saygı algısının azaldığı söylenebilir. Denilebilir ki, aynı işletmede uzun süre çalışmak kimi zaman, çalışanların liderle olan ilişkilerini yıpratabilmektedir. Ek olarak işletmede çalışma süresi arttıkça bireyler zamanla işletmenin değerlerinin kendi değerli ile çelişebildiğini fark edebilir. Bunlar ise işletme içerisinde tutum ve davranışlarını etkileyebileceğinden (Erdogan vd., 2004: 304) çalışanın, yöneticisi ile olan ilişkisini de etkileyebilecektir. Diğer taraftan, tüm bunların bağlılık boyutu açısından da geçerli olduğu ifade edilebilir. Çünkü bağl1lık boyutu açısından da işletme deneyimi, çalışanların bağlılık algısı üzerinde negatif bir etkiye sahiptir.

Sektör deneyiminin artışı ise mesleki saygı algısını doğru orantılı olarak etkilemektedir. Aynı sektörde uzun süre çalışmak, daha önce ifade edildiği üzere, çalışanların iş becerileri yönüyle daha yetkin hale gelmesine ve işte daha üretken olabilmesine zemin hazırlayabilmektedir. Bu da çalışanın, liderin verdiği yönetsel talimatları daha hızlı ve istenilen şekilde yerine getirebilmesi nedeniyle ikilinin ilişkisine olumlu yönde yansımaktadır. Ek olarak, tüm bunların bağlılık boyutu açısından da geçerli olduğu ifade edilebilir. Çünkü bu boyut açısından da sektör deneyimi, çalışanların bağlılık algısı üzerinde pozitif bir etkiye sahiptir.

Bağlılık boyutu açısından etkili olan üçüncü bağımsız değişken eğitim durumudur. Buna göre eğitim seviyesi ile bağlılık algısı arasında ters yönlü bir ilişki vardır. Bir diğer ifadeyle bağl1lık algısının artması için eğitim seviyesinin azalması gerekmektedir. Bu sonuç, bazı çalışmalardan farklılık arz etmektedir. Örneğin, Lee (2008) eğitim seviyesi ile genel LÜE algısının ilişkili olmadığına değinirken, Chen vd. (2007) ile Bell vd. (2015) bu iki değişkenin doğru orantılı bir şekilde değiştiğini ifade etmektedir. İlk bakışta, eğitim durumunun artması ile yaratıcı düşünme, problem çözme ve planlama yapma gibi becerilerin de artabilmesi (Bell vd., 2015: 54) ve bunların da işe olumlu yansıyarak çalışanın yöneticisi ile iletişimini kuvvetlendirebilmesi nedeniyle, eğitim-LÜE algısı ilişkisinin doğru orantılı bir şekilde değişmesi daha mantıklı durmaktadır. Ancak bazen yüksek eğitim seviyesi ile gelen becerilerin de özgüveni ile çalışanlar, piyasada daha kolay iş bulabileceğini düşünebilmekte, bu da örgüte ve lidere bağlılığı azaltabilmektedir. Düşük eğitim seviyesine sahip çalışanların ise iş piyasasında talep gören becerilerden mahrum olabilmesi, bu çalışanlar açısından mevcut işin değerini yükseltebilmektedir. Böylelikle bu çalışanların yöneticilerine daha sadık olabileceği akla gelebilir. İşte bu neden, eğitim seviyesi ile bağlılık algısının ters yönlü ilişkisini açıklayabilir. Ek olarak, eğitim seviyesi düşük olan çalışanlar, entelektüel bilgi birikimlerinin düşük olabilmesinin de etkisiyle, yöneticilerini 
oldukça bilgili, işi ile ilgili bütün konulara vakıf, liderlik vasıflarına sahip biri olarak değerlendirebilir (Green, 2008: 107). İşte bu da düşük eğitim seviyesine sahip çalışanların bağl1lık algılarını yine yükselebilecek bir unsur olarak değerlendirilebilir.

LÜE'nin alt boyutlarını oluşturan etki, bağlılık ve mesleki saygı açısından sektör deneyiminin önemi, diğer değişkenlere nazaran daha ön plandadır. Çünkü her bir boyutta etkisi olan değişken sektör deneyimidir ve her bir alt boyutu olumlu şekilde etkilemektedir. Sektör deneyimi ile ilgili buraya kadar ki ifadelerimizi genel bir çerçeveye oturtmak gerekirse şunlar söylenebilir. Beşeri sermaye teorisi dayanak yapılarak (Kim vd., 2015: 217), bir bireyin sektör deneyiminin artması ile iş ile ilgili özel bilgi ve becerilerinin arttığı, yaratıcılık ve problem çözme gibi becerilerinin gelişerek (Volmer vd., 2012: 460) iş üzerindeki kontrolünü artırdı̆̆ dile getirilebilir. Aynı zamanda bu çalışanların kritik zamanlarda sorumluluk alabilmesi de liderle olan etkileşimlerini artırabilmektedir (Kim vd., 2015: 220). Bu durum konaklama işletmeleri açısından özellikle yüksek sezonda büyük önem taşımaktadır. Zira bu dönemlerde kimi zaman, iş akışı aksayabilmektedir. Bu noktada bazı çalışanların sorumluluk alarak -tabiri caizse- dümenin başına geçmesi ve iş akışının normal seyrine dönebilmesi için problemlere karşı yenilikçi çözüm önerileri getirebilmesi gereklidir. İşte bu noktada, sektör deneyimi daha fazla olan çalışanlar, diğerlerine göre daha avantajlı bir konuma sahiptirler. 


\section{KAYNAKÇA}

Alparslan, A. ve Oktar, Ö. (2015). Türkiye'de Lider-Üye Etkileşimi Kuramına Dair Makale Kapsamındaki Araştırmalar: Bibliyometrik Bir İçerik Analizi. Business and Economics Research Journal, 6(1), 107-123.

Baş, T., Keskin, N. ve Mert, S. (2010), Lider Üye Etkileşimi (LÜE) Modeli ve Ölçme Aracının Türkçe'de Geçerlik ve Güvenilirlik Analizi, Ege Akademik Bakış, 10 (3), 1013-1039.

Bell, C., Rvanniekerk, R., Nel, P. (2015). The relationship between some demographic variables and leadership effectiveness among local government managers in South Africa. African Journal of Business Management, 9(2), $50-58$.

Bolat, O. (2011a). Öz Yeterlilik ve Tükenmişlik İlişkisi: Lider-Üye Etkileşiminin Aracılık Etkisi. Ege Akademik Bakış, 11(2), 255-266.

Bolat, O. (2011b). Lider Üye Etkileşimi ve Tükenmişlik İlişsisi. “İşGüç” Endüstri İlişkileri ve İnsan Kaynakları Dergisi, 13(2), 65-80.

Bolat, O., Bolat, T., Seymen, O., Yüksel, M. (2017). İstismarcı Yönetim ve Tükenmişlik: Lider-Üye Etkileşimi ve Güç Mesafesinin Düzenleyici Etkisi. Balıkesir Üniversitesi Sosyal Bilimler Enstitüsü Dergisi, 20(38), 85-111.

Brouer, R., Duke, A., Treadway, D., Ferris, G. (2009). The moderating effect of political skill on the demographic dissimilarity - Leader-member exchange quality relationship. The Leadership Quarterly 20, 61-69.

Can, A. (2018). SPSS ile Bilimsel Araştırma Sürecinde Nicel Veri Analizi. Ankara: Pegem Akademi.

Cevrioğlu, E. (2007). Lider-Üye Etkileşimi ile Bireysel ve Örgütsel Sonuçlar Arasındaki İlişki: Ampirik Bir İnceleme. Yayınlanmamış Doktora Tezi. Afyonkarahisar Kocatepe Üniversitesi Sosyal Bilimler Enstitüsü.

Cha, J. ve Borchgrevink, C. (2018). Leader-Member Exchange (LMX) and Frontline Employees' Service-Oriented Organizational Citizenship Behavior in the Foodservice Context: Exploring the Moderating Role of Work Status, International Journal of Hospitality \& Tourism Administration, 19:3, 233-258.

Chow, C., Lai, J., Loi, R. (2015). Motivation of travel agents' customer service behavior and organizational citizenship behavior: The role of leader-member exchange and internal marketing orientation. Tourism Management, 48, 362369.

Çekmecelioğlu, H. ve Ülker, F. (2014). Lider - Üye Etkileşimi ve Çalışan Tutumları Üzerindeki Etkisi: Eğitim Sektöründe Bir Araştırma. Kocaeli Üniversitesi Sosyal Bilimler Dergisi, 28, 35-58.

Çokluk, Ö. (2010). Lojistik Regresyon Analizi: Kavram ve Uygulama. Kuram ve Uygulamada Eğitim Bilimleri. 10(3), 1357-1407.

Çokluk, Ö., Şekercioğlu, G., Büyüköztürk, Ş. (2014). Sosyal Bilimler için Çok Değişkenli İstatistik, SPSS ve Lisrel Uygulamaları. Ankara: Pegem Akademi.

Dansereau, F., Cahman, J. ve Graen, G. (1973). Instrumentality Theory and Equity Theory as Complementary Approaches in Predicting the Relationship of Leadership and Turnover among Managers. Organızatıonal Behavior and Human Performance, 10, 184-200.

Demirci, B. (2017). Restoran İşletmelerinde Rol Stresi ve Lider-Üye Etkileşiminin İşten Ayrılma Niyetine Etkisi. Yayınlanmamış Doktora Tezi. Eskişehir Osmangazi Üniversitesi Sosyal Bilimler Enstitüsü.

Dienesch, R. ve Liden R. (1986). Leader-Member Exchange Model of Leadership: A Critique and Further Development. The Academy of Management Review, 11 (3), 618-634.

Dulebohn, J., Bommer, W., Liden, R., Brouer, R., Ferris, G. (2012). A Meta-Analysis of Antecedents and Consequences of Leader-Member Exchange: Integrating the Past With an Eye Toward the Future. Journal of Management, 38(6), 1715-1759.

Epitropaki, O. ve Martin, R. (1999). The impact of relational demography on the quality of leader-member exchanges and employees' work attitudes and well-being. Journal of Occupational and Organizational Psychology, 72, 237240.

Erdogan, B., Kraimer, M., Liden, R. (2004). Work Value Congruence and Intrinsic Career Success: The Compensatory Roles Of Leader-Member Exchange And Perceived Organızatıonal Support. Personnel Psychology, 57, 305-332.

Estiri, M., Amiri, N., Khajeheinan, D., Rayej, H. (2018). Leader-member exchange and organizational citizenship behavior in hospitality industry: a study on effect of gender. Eurasian Bus Rev, 8, 267-284.

Eşitti, B. ve Kasap, M. (2019), The impact of leader-member exchange on lodging employees' dynamic capacities: The mediating role of job satisfaction. Tourism and Hospitality Research, in press. doi: 10.1177/1467358419826397.

Field, A. (2009). Discovering Statistics Using Spss. USA: Sage Publications.

Garg, S. ve Dhar, R. (2016). Extra-Role Customer Service: The Roles of Leader-Member Exchange (LMX), Affective Commitment, and Psychological Empowerment, International Journal of Hospitality \& Tourism Administration, 17:4, 373-396.

Gerstner, C. ve Day, D. (1997). Meta-Analytic Review of Leader-Member Exchange Theory: Correlates and Construct Issues. Journal of Applied Psychology, 82(6), 827-844.

George, J. ve Jones, G. (2012). Understanding and Managing Organizational Behavior. US: Pearson.

Green, C. (2008). Leader member exchange and the use of moderating conflict management styles: Impact on relationship quality. International Journal of Conflict Management, 19(2), 92-111. 
Green, S., Anderson, S., Shivers, S. (1996). Demographic and Organizational Influences on Leader-Member Exchange and Related Work Attitudes. Organizational Behavior and Human Decision Processes, 66(2), 203-214.

Ilies, R., Nahrgang, J., Morgeson, F. (2007). Leader-Member Exchange and Citizenship Behaviors: A Meta-Analysis. Journal of Applied Psychology, 92(1), 269-277.

Joo, B. (2010). Organizational Commitment for Knowledge Workers: The Roles of Perceived Organizational Learning Culture, Leader-Member Exchange Quality, and Turnover Intention. Human Resource Development Quarterly, 21(1), 69-85.

Kaşlı, M. ve Seymen, O. (2010). Kişilik Özellikleri, Lider-Üye Etkileşimi ve Tükenmişlik İlişkisi. Dumlupınar Üniversitesi Sosyal Bilimler Dergisi, 27, 109-122.

Katı, Y. (2016). İşgörenlerin Politik Becerileri ve Kariyer Başarısı İlişkisi: Lider Üye Etkileşiminin Aracılık Etkisi. Yayınlanmamış Yüksek Lisans Tezi. Balıkesir Üniversitesi Sosyal Bilimler Enstitüsü.

Kim, B. ve George, R. (2005). The Relationshıp Between Leader-Member Exchange (LMX) and Psychological Empowerment: A Quick Casual Restaurant Employee Correlation Study. Journal of Hospitality \& Tourism Research, 29(4), 468-483.

Kim, B., Lee, G. ve Carlson, K. (2010), An examination of the nature of the relationship between Leader-MemberExchange (LMX) and turnover intent at different organizational levels, International Journal of Hospitality Management, 29, 591-597.

Kim, S., O'neill, J. ve Cho, H. (2010), When does an employee not help coworkers? The effect of leader-member exchange on employee envy and organizational citizenship behavior, International Journal of Hospitality Management, 29, 530-537.

Kim, T., Liu, Z., Diefendorff, J. (2015). Leader-member exchange and job performance: The effects of taking charge and organizational tenure. Journal of Organizational Behavior, 36, 216-231.

KTB (Kültür ve Turizm Bakanlığı). (2019). Turizm Yatırım ve İşletme (Bakanlık) Belgeli Tesis İstatistikleri. Erişim Tarihi: 01.03. 2019. http://yigm.kulturturizm.gov.tr/TR-201136/turizm-yatirim-ve-isletme-bakanlik-belgeli-tesisistati-.html.

Kwon, S. M., ve Lim, Y. J. (2007). The State-Trait Anxiety Inventory, Trait Version: Examination of a Method Factor. Korean Social Science Journal, 34(2): 105-122.

Lai, J., Chow, C, ve Loi, R. (2018). The interactive effect of LMX and LMX differentiation on followers' job burnout: evidence from tourism industry in Hong Kong, The International Journal of Human Resource Management, 29:12, 1972-1998.

Liao, S., Hu, D., Chung, H. (2009). The relationship between leader-member relations, job satisfaction and organizational commitment in international tourist hotels in Taiwan, The International Journal of Human Resource Management, 20:8, 1810-1826.

Liden, R. ve Graen, G. (1980). Generalizability of the Vertical Dyad Linkage Model of Leadership. The Academy of Management Journal, 23(3), 451-465.

Liden, R. ve Maslyn, J. (1998). Multidimensionality of Leader-Member Exchange: An Empirical Assessment through Scale Development. Journal of Management, 24(1), 43-72.

Liden, R., Erdogan, B., Wayne, S., Sparrowe, R. (2006). Leader-member exchange, differentiation, and task interdependence: Implications for individual and group performance. Journal of Organizational Behavior, 27, 723746.

Liden, R., Sparrowe, R. ve Wayne, S. (1997). Leader-member exchange theory: The past and potential for the future. Research in Personnel and Human Resources Management, 15, 47-119.

Liden, R., Wayne, S., Stilwell, D. (1993). A Longitudinal Study on the Early Development of Leader-Member Exchanges. Journal of Applied Psychology, 78(4), 662-674.

Loi, R., Chan, K., Lam, L. (2014). Leader-member exchange, organizational identification, and job satisfaction: A social identity perspective. Journal of Occupational and Organizational Psychology, 87, 42-61.

Martin, R., Epitropaki, O., Thomas, G., Topakas, A. (2010). A Review of Leader-Member Exchange Research: Future Prospects and Directions. International Review of Industrial and Organizational Psychology, 25, 35-87.

Martin, R., Guillaume, Y., Thomas, G., Lee, A., Epitropaki, O. (2016). Leader-Member Exchange (LMX) and Performance: A Meta-Analytıc Review. Personnel Psychology, 69, 67-121.

Martin, R., Thomas, G., Legood, A., Russo, S. (2018). Leader-member exchange (LMX) differentiation and work outcomes: Conceptual clarification and critical review. J. Organ. Behav., 39: 151-168.

Moital, M., Vaughan, R., Edwards, J., Peres, R. (2009). Determinants of Intention to Purchase Over the Internet. Anatolia, 20:2, 345-358.

Murphy, S. ve Ensher, E. (1999). The Effects of Leader and Subordinate Characteristics in the Development of LeaderMember Exchange Quality. Journal of Applied Social Psychology, 29 (7), 1371 -1394.

Ordun, G. ve Aktaş, H. (2014). Lider-üye etkileşimi faktörlerinin liderler ve astlar tarafindan karş1lıklı algılanması: Bir perakende işletmesi çalışanları üzerinde araştırma. 43(1), 120-135.

Pelit, E. (2008). İşletmelerde İşgören Güçlendirmenin İşgörenlerin İş Doyumuna Etkisi: Otel İşletmelerinde Bir Araştırma. Yayınlanmamış Doktora Tezi. Gazi Üniversitesi Eğitim Bilimleri Enstitüsü.

Peng, C. ve So, T. (2002). Logistic Regression Analysis and Reporting: A Primer, Understanding Statistics, 1:1, 31 -70. 
Pichler, S., Livingston, B., Yu, A., Varma, A., Budhwar, P., Shukla, A. (2019). Nationality diversity and leader-Member exchange at multiple levels of analysis: Test of a cross-level model. Equality, Diversity and Inclusion: An International Journal, 38 (1), 20-39.

Schermelleh-Engel, K., Moosbrugger, H. ve Müller, H. (2003), Evaluating the Fit of Structural Equation Models: Tests of Significance and Descriptive Goodness-of-Fit Measures. Methods of Psychological Research Online, 8(2), 2374.

Sekaran, U. (2003). Research Methods for Business. (Fourth Edition). NY: John Wiley \& Sons, Inc.

Şencan, H. (2005). Sosyal ve Davranışsal Ölçümlerde Güvenilirlik ve Geçerlik. Ankara: Seçkin Kitabevi.

Tabachnick, B. ve Fidell, L. (2007). Using Multivariate Statistics. USA: Pearson.

Tanrıverdi, H. ve Kahraman, O. (2016). 5 Yıldızlı Otel İşletmelerinde Lider-Üye Etkileşimi ve İşe Yabancılaşma İlişkisi: Marmaris ve İstanbul Destinasyonlarında Bir Araştırma. Dokuz Eylül Üniversitesi Sosyal Bilimler Enstitüsü Dergisi, 18(3), 463-493.

Tsui, A. ve O'Reilly, C. (1989). Beyond Simple Demographic Effects: The Importance of Relational Demography inSuperior-Subordinate Dyads. The Academy of Management Journal, 32 (2), 402-423.

Tsui, A., Egan, T., O'Reilly, C. (1992). Being Different: Relational Demography and Organizational Attachment. Administrative Science Quarterly, 37 (4), 549-579.

Volmer, J., Spurk, D., Nessen, C. (2012). Leader-member exchange (LMX), job autonomy, and creative work involvement. The Leadership Quarterly, 23, 456-465.

Wang, C. (2016). Does leader-member exchange enhance performance in the hospitality industry?: The mediating roles of task motivation and creativity", International Journal of Contemporary Hospitality Management, 28 (5), 969 987.

Wayne, S., Shore, L., Bommer, W., Tetrick, L. (2002). The Role of Fair Treatment and Rewards in Perceptions of Organizational Support and Leader-Member Exchange. Journal of Applied Psychology, 87 (3), 590-598.

Wayne, S., Shore, L., Liden, R. (1997). Perceived Organizational Support and Leader-Member Exchange: A Social Exchange Perspective. The Academy of Management Journal, 40 (1), 82-111. 